Historic, Archive Document

Do not assume content reflects current scientific knowledge, policies, or practices. 

62,57
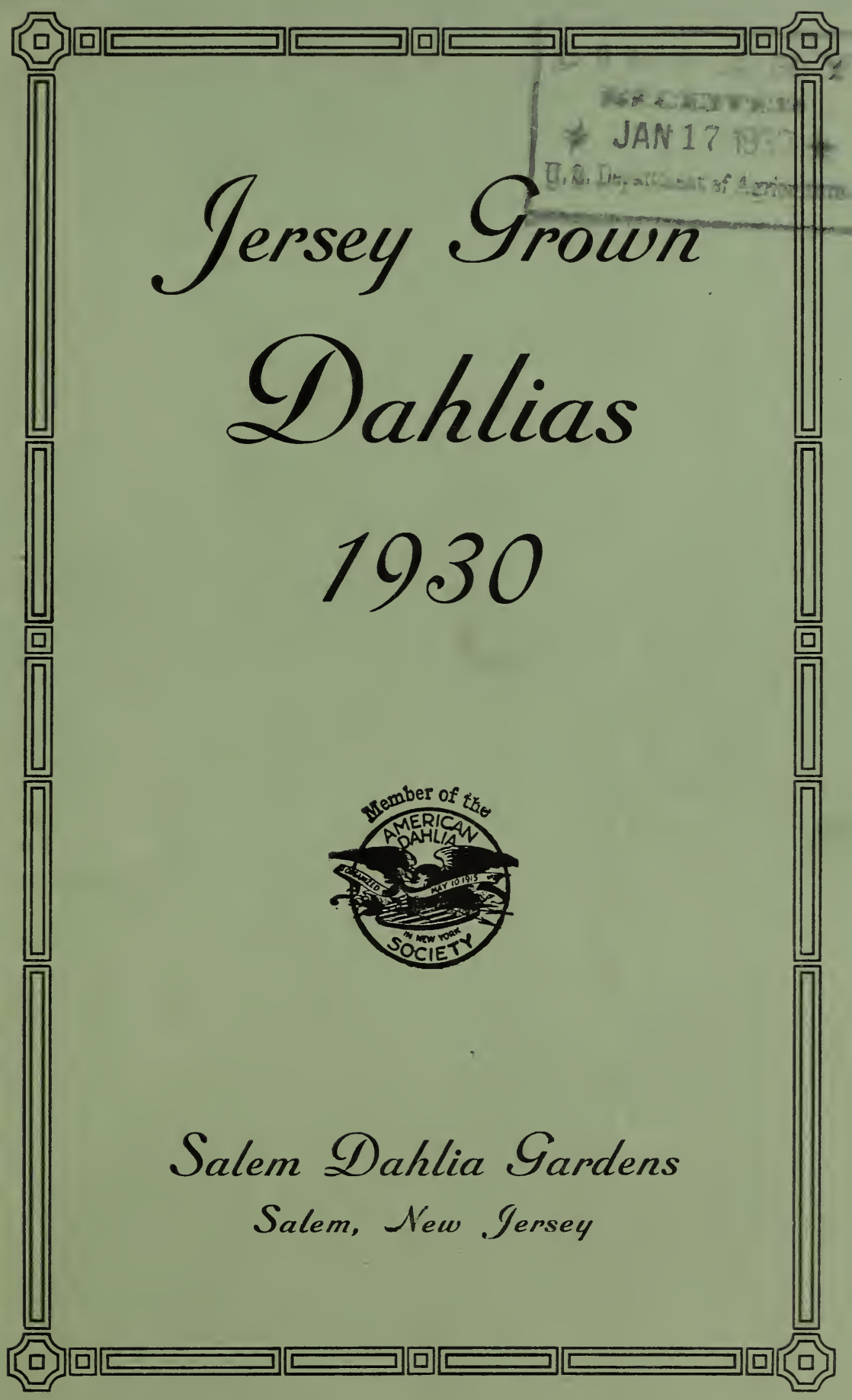



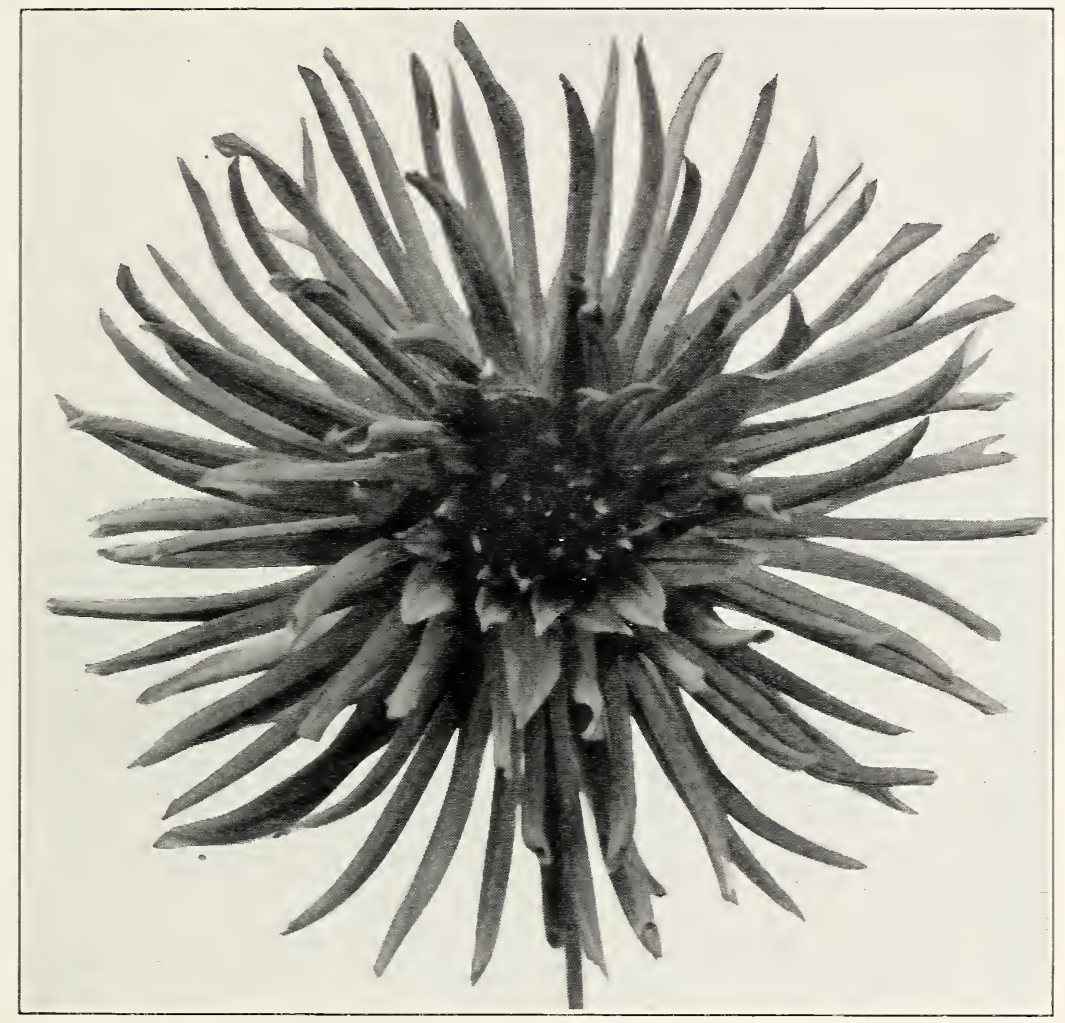

AMERICAN TRIUNPH

Description on page 4 


\section{\& GRETINGS \&}

$\mathrm{W}^{\mathrm{n}}$

E take great pleasure in presenting this our 1930 illustrated descriptive catalogne of dahlias as grown in New Jersey. Realizing that an enor. mous number of dahlias is confusing and can serve no gcod purpose, we have listed only those of superior merit.

We desire to call your attention to the choice New Jersey originations, especially the new ones of this year's introduction. New Jersey dahlias have become famous the country over, not only for their large size and stiff stem, but for their wondrous beauty in both formation and color; they have won the most coverted prize at the American Dahlia Society Show at New York for the past five years.

We desire to thank our many customers for their liboral patronage during the past year and for the many kind letters telling us of the success thoy had with our dahlias, both in the garden and showroom.

We ceaslessly endeavor to maintain a reputation for fairness, integrity an trustworthiness-to do a clean business, satisfactory alike to us and to our customers. Our best business comes from thos a who send us their orders year after year; they know they can depend on us for good stock and an absolutely square deal. We are proud of these customers-proud of the reputation our dahlias have made, but we are not satisfied. Each succeeding year will find us trying to improve our methods in every department-growing, packing, shipping-to the end that we may botter serve the people who look to us for good dahlias.

We did not spray our growing plants in the fields the past season and dug only those that vigorously withstood the ravages of the insects and the adverse weather conditions, therefore our tubers should be as healthy as it is possible for them to be.

Visitors are welcome at all times. Do not fail to see our dahlias during blooming season. Our trial grounds are located only two miles from Salem.

\section{SALEM DAHLIA GARDENS}

WM. H. NUNEVILLER

Office, 236 Grant St.

Salem, N. J., U. S. A.

Telephone-Salem 286 


\title{
GENERAL INFORMATION
}

ORDER EARLY, directing us when to ship stock. Early orders are solicited to prevent disappointment in case our stock of those selected has been depleted. If you do not find the varieties you want in this collection, write us. We have many not catalogued.

WE GUARANTEE all "tubers true to name and their safe arrival if sent by Express or Mail to points within the United States. We cheerfully replace any that should prove otherwise. Orders are filled from field grown tubers, showing eyes, alid free from stunt or disease. We do not substitute unless requested.

GREEN PLANTS. We strongly recommend green plants. We have received many very pleasing reports on the plants sent out last Spring and there is a greater demand for them this season. Complete green plant list ready March 25. Send for a copy.

TERMS. Remittance with order. All retail ordors are delivered prepaid. Foreign orders should be accompanied with an International Post Office or Express Money Order, or a check or draft on a U. S. Bank in par U. S. Funds.

REFERENCES. Dun's, Bradstrøet's, or Salem National Bank and Trust Co.

FREE TUBERS. On all retail orders for tubers sent in during January and February we will allow you to select from this catalogue tubers to the amount of $15 \%$ of your order; on March orders tubers to the amount of $10 \%$ of your order, and on April, May and June orcers tubers to the amount of $5 \%$ of your order. This does not apply to bargains or collections which have been priced very low.

NOTE: We will use the new dahlia classifications next year as published on page 16 .

\section{SALEM DAHLIA GARDENS}

\author{
W. H. NUNEVILLER
}

Office, 236 Grant St.

Salem, N. J., U. S. Á.

Telephone—Salem 286 


\section{A H L I A S}

Key-C., Cactus; D., Decorative; P., Peony; S., Show; H. C., Hybrid Cactus ; H. D., Hybrid Decorative.

AMBASSADOR, C. (Broomall)-A large filower of pleasing form; color is a soft, yollow buff, shaded salmon-pink; a stiff upright stem. A great prize-winner.

Tubers, \$1.00; Plants, \$.75

ALICE WHITTIER, H. C., (Reed)-Color a very delicate shade of primrose yellow; exhibition sized flowers and exceptionally deep. Stiff stems and good habit of growth.

Tubers, \$1.50; Plants, \$.75

ADELINE C. LORBEER, C., (BroomalI)-One of the best pure red cactus dahlias in cultivation. The medium large flowers are produced on fine stems and stand the hot sun well, without bleaching or burning and keeps well as a cut flower, certainly the best of its color for cutting.

Tubers, $\$ 2.00 ;$ Plants, $\$ 1.0 \mathrm{C}$

AMARILLO GRANDE, H. D. (Broomall)-Light yellow. Compared with Sunny South the petals are more broad and the flowers are much larger; in Iact, they are enormous and are produced in abundance.

Tubers, $\$ 1.50$; Plants, $\$ .75$

AZTEC GLORY, D., (Broomall) - It is a clear picric yellow with deep massive flowers of unusual and most artistic formation held on strong erect stems. Bush abou' $2 \mathrm{r} / 2$ feet high with glossy green foliage, having somewhat the appearance of holly。

Tubers, \$5.00; Plants, $\$ 2.50$

*AMERICAN TRIUMPH, C., (A. D. F.)-The sensational seedling at the A. D. S. Show. Undoubtedly the finest true Cactus Dahlia ever produced. Such an unusual coloring, the brightest shade of pure oriential red without a trace of any other color. The large, deep blossoms have good substance and are held facing to upright on extra good stems over a medium tall bush. It will not only make a most worthy addition to the Cactus class, in which there are so fow good exhibition varieties but an exceptionally good garden and cut flower, as there is no better keeping Dahlia in existence. Winner of the American Home Swoepstakes for the most outstanding new seedling in the entire Show in the largest and strongest class of seedlings ever exhibited at New York.

Tubers, $\$ 10.00$; Plants, $\$ 5.00$

BIG CHIEF, H. D., (Success)-Color rich autumn shades; general effect is salmon-buff. Immense fiowers carried erect on long, stiff stems; free bloomers. Stock limited.

Tubers, $\$ 7.50$ : Plants, $\$ 3.75$

BARBARA REDFERN, D., (Redfern)-Color is a wondrous combination of old rose and old gold. Outside of petals is dull gold the reverse delicate old rose. Bloom is very large and borne on stiff stems. Excellent bush growth and prolific bloomer.

Tubers, $\$ 2.00 ;$ Plants, $\$ 1.00$

*CITY OF TRENTON, D., (Prentice-Fisher \& Masson)-A large exhibition decorative borne on top of cane-like stem. An autumn colored dahlia defying adequate description. The face of petals, a rich glowing tangerine, reverse crushed-strawberry red. The petals curl gracefully. giving a two toned effect and creating an impression of whorls or tongues of flame radiating from a full center. Tubers, $\$ 3.50$; Plants, $\$ 1.75$

*Varities prefixed with an (*) are New Jersey originations. 
*CASPER G. WARE, D. (Bowen-S. D. G.) -Our 1926 introduction which has given universal satisfaction wherever grown. Flowers are large, regularly formed and produced profusely on strong stems. Color bright clear violet rose. Bush medium to dwarf and very vigorous. Blossom is an extra good keeper and has exceptional exhibition and commercial qualities.

Tubers, $\$ .75$

CARNIVAL, D. (Barker)-A gigantic scarlet, reverse sulphur yellow. Flower is so filled with red and rellow petals that it makes a striking autumn effect. Flowers held high above the foliage on cane like stems.

Tubers, $\$ 2.00$; Plants, $\$ 1.00$

*CORA BUTTERWORTH, D. (Chapman)-A giant bloom with a long, excellent stem which holds the bloom out and up. Blooms are well formed with many petals and high centers. Color is a rich glistening primrose yellow without a trace of any other color. The outstanding decorative at the New York Show. Tubers, $\$ 10.00$; Plants, $\$ 5.00$

*DAYLO, D. (A. D. F.) -Meaning "Behold tho light of day." In this regular type decorative we have the brightest autumi shades imaginable, apricot orange and cadmium, mostly orange for the ninopen petals. The bush is rery hardy and the strong stems hold the large flowers facing to upright. Received A. D. S. Certificate of Merit at the trial gardens at Stoors, Conn., 1929.

Plants only, $\$ 5.00$

DERRILL W. HART, D. (Broomall)-Capucine yellow shading to grenadine red, in cool weather almost copper color. The large, well formed flowers of this variety are held erect on fine stems.

Tubers, $\$ 5.00$; Plants, $\$ 2.50$

*EMMA MARIE, H. C. (Dahliadel)-A favorite because of its pleasing shade of clear pink with a creamy white center and its combination of exhibition and commercial qualities not found in many dahlias. A robust grower, producing deep, full-centred blooms averaging 8 inches in diameter on 3 to 4 font stems in ordinary field culture.

Tubers, $\$ .75$

*EASTERN STAR, D. (Dahliadel)-Color a soft saffron yellow with old gold shadings. Flowers of great substance and good keeping qualities with full centers, held on strong, erect stems. Excellent bush growth and free flowering. Grows 10 inches without forcing.

Tubers, $\$ 1.50$; Plants, $\$ .75$

EL REY, D. (O. \& C.) -A large beautiful flower of the Jersey Beacon type. Color orange shadiing to deeper orange at center. Very prolific and insect resistant. Winner at Los Angeles and other shows.

Tubers, $\$ 10.00$; Plants, $\$ 5.00$

EVELYN MORRIS, D. (BroomalI)-Another new color in this very large decorative and when we say it is a bright purple we do not give this dahlia justice. A tall grower with blooms held erect.

Tubers, $\$ 10.00$; Plants, $\$ 5.00$

*ELITE GLORY, D. (Kennedy)-A monstrous flower, but strange to say is not awkward but is both pleasing and spectacular in appoarance. The colcr is a brilliant rich red without any apparent purple or maroon shading. A good keeper and a winner whererer shomn. Scored 92 at A. D. S. trial grounds.

Tubers, $\$ 1.50$; Plants, $\$ .75$ 
ELIZA CLARK BULL, D. (Boston)-It gives ils groat pl zasure to recommend this beautiful white dahlia. It is regularly formed and very large, producing 10 to 11 inch flowers in the hoitest weather and did not burn a particle right out in the open field. Excellent stems and generous blooms.

Tubers, \$1.25; Plants, $\$ .75$

EL GRANADA, H. C. (Boston)-All immense orange; the petals twist and interlace, showing at the tips a creamy yellow reverse. Good stems.

Tubers, $\$ 1.00$; Plants, $\$ .75$

ELDORADO, D. (Boston)-A very large vivid goid blossom which has deptl. The flower has substance and the stem is good. Dwarf bush.

Tubers, \$1.00; Plants, \$.75

ELLINOR VANDERVEER, D. (Seal)-An incomparable dahlia of exquisite beauty and great size, having every desirable quality. One of the best dahlias evor brought from the Pacific coast. Blossoms are of glowing satiny rose pink, and are of great depth and substance and held far above a sturdy bush on long stift stems. Prolific bloomer and great prize winner.

Tubers, $\$ 1.00$

EAGLE ROCK BEAUTY, H. D. (Broomall)-A more beautiful combination of pink and cream than is displayed in this glorious creation would be difficult to imagine. It is in a class by itself and unanimously admired by all who have seen it. It is vigorous in growth, with good habits and strong stems holding perfectly erect the inmmense blooms which aro full to the center and produced in abundance until frost.

Tubers, \$2.50; Plants, $\$ 1.25$

EAGLE ROCK SUNSHINE, C. (Broomali)-The color is a deep shade of yellow, the flowers are very large and held perfiectly erect on strong stems. It shows no tendency to become pendant ever under the most unfavorable conditions. Blooms are full to the center until frost.

Tubers, $\$ 1.00$

EAGLE ROCK JEWEL, H. C. (Broomall)-Cream overlaid cameo pink (shell pink), this combination making it a most beautiful dahlia. The large flowers are borne on strong stems; it is a vigorous grower and a free bloomer.

Tubers, $\$ 4.00$; Plants, $\$ 2.00$

EAGLE ROCK GEM, C. (Broomall)-Maize yellow shaded orient pink; this is certainly the finest shaped strong stemmed dahlia yet produced; its form is much finer than Ambassador and the flowers always stand perfectly erect.

Tubers, $\$ 7.50$; Plants, $\$ 3.75$

*ELKRIDGE, H. C. (Griffith)—A beautiful white with strong stem, robust grower, good substance, continncus blcomer and a good commercial variety.

Tubers, $\$ 2.00 ;$ Plants, $\$ 1.00$

*EVA L. QUADLING, D. (Quadling A. D. F.)-Immense full-centered blooms, held well above the foliage, petals folding almost to the stem. Color carmine and spectrum blended, jack same with pale mauve veining; center oxblood red. Ideal bush growth and a medium free bloomer. An excellent variety for both exhibition and cutting, being a good keeper.

Tubers, \$5.00; Plants, $\$ 2.50$

*EDNA FERBER, H. C. (Fisher \& Masson)-Color a glistening coral, shading to old gold at the base of petals. Petals curled and twisted, making a very full flower. One of the largest hybrid cactus varieties, and a winner wherever shown.

Tubers, $\$ 3.00$; Plants, $\$ 1.50$ 


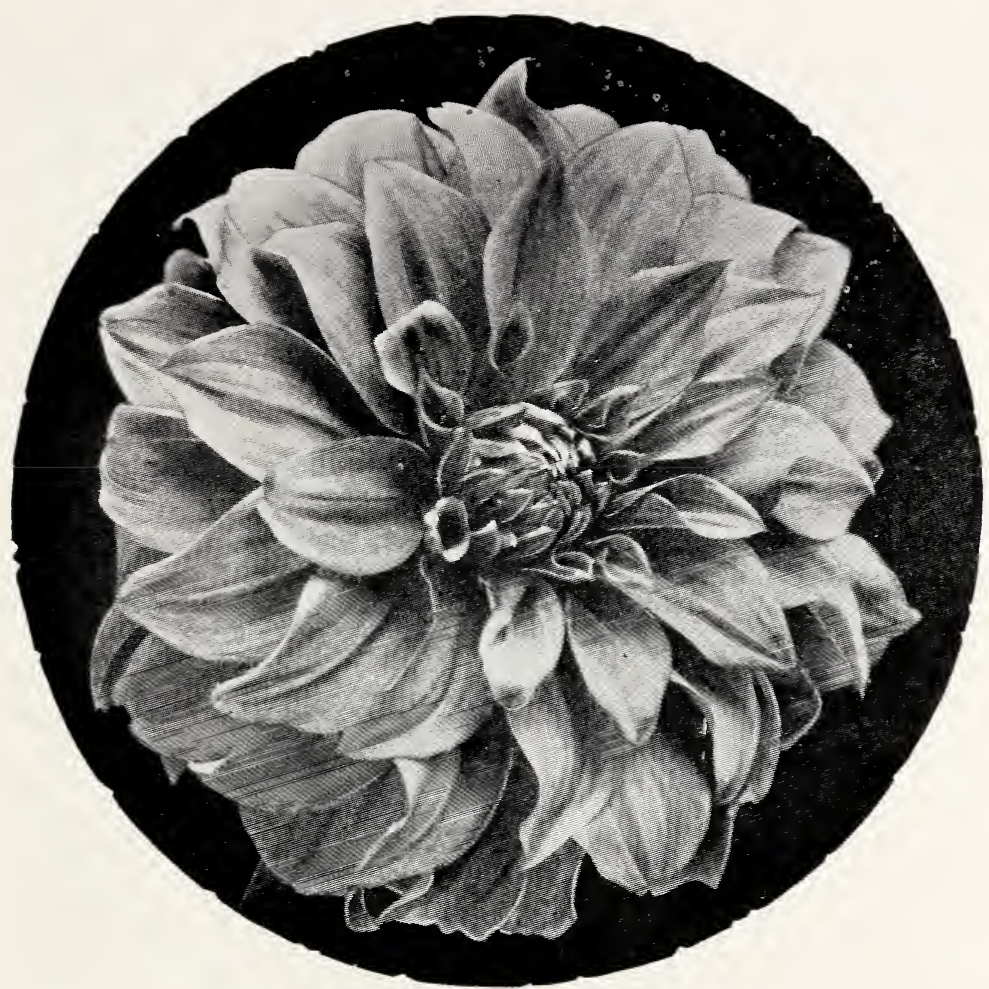

BARBARA REDFERN

Description on page 4

FAITH GARIBALDI, D.(Garibaldi)-This is a superb rose pink of great size. Does not require heavy disbudding for immense blooms. Bloom is held straight on a long, stiff stem.

Tubers, $\$ 1.50$; Plants, $\$ .75$

FLAMING METEOR, D. (Barker) -A brilliant vermilion or orange. Blooms large and carried on erect stems. A popular cut flower variety.

Tubers, $\$ 2.00$; Plants, $\$ 1.00$

FORDHOOK MARVEL, D. (Burpee)-A giant in size, carrying its bloom on strong, cane-like stems. The color is a lovely shade of peach red, shading to strawberry pink. The whole flower is suffused with a sparkling salmon-orange sheen of metallic luster. $\quad$ Tubers, $\$ 7.50$; Plants, $\$ 3.75$

*FORT MONMOUTH, H. C. (Kemp)-The predominating color is a rich claret with brightness unusual in darker tones. Flowers full centered and well formed borne on stiff stem well above the foliage. Prolific grower and bloomer, tall bush with flowers a foot in diameter.

Tubers, $\$ 7.50$; Plants, $\$ 3.75$

*GOV. MORGAN F. LARSON, D. (Lyndora Gardens)-Color a clear bright gold. Wimner of Gov. Larson's cup at Trenton as most worthy undisseminated dahlia; also best yellow in the open classes at Camden. A large but not ccarse bloom.

Tubers, $\$ 10.00 ;$ Plants, $\$ 5.00$ 


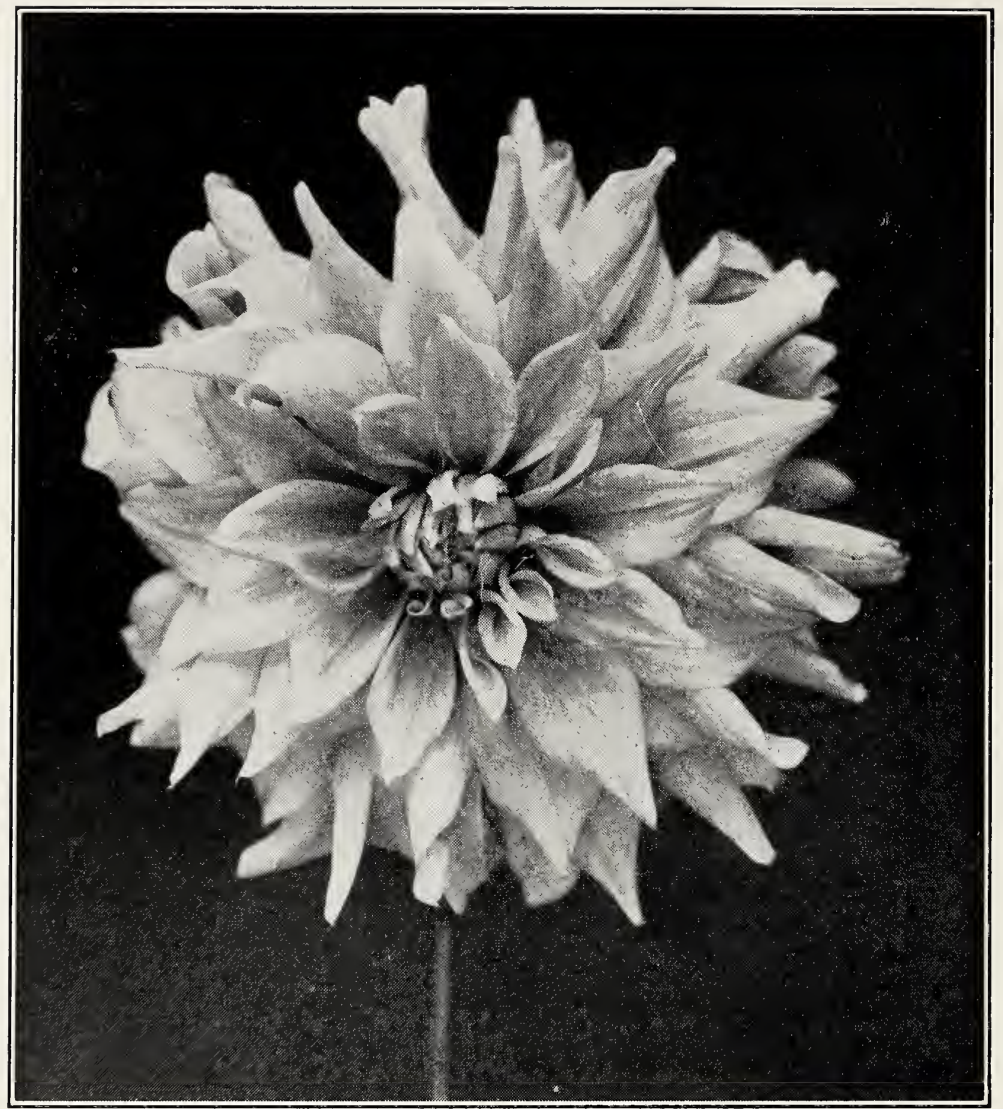

EAGLE ROCK BEAUTY

Description on page 6

GOODNIGHT, D. (Broomall)-Color a blood red shaded maroon. A very largo idahlia with a good stem. Rugged grower.

Tubers, $\$ 10.00 ;$ Plants, $\$ 5.00$

*GRACE RICORDS, D. (Ricords-Dahliadel)-A decided outstanding novelty of last year. Flowers are large with full, high centers, tipped and suffused lavender on a white ground, petals numerous and decidedly cleft, giving the flower an artistic formation. Bush a tall, open and strong grower.

Tubers, $\$ 10.00$; Plants, $\$ 5.00$

HARRY MAYER, D. (Seltsam)-A fine exhibition dahilia that holds an ieven full center, has size, depth and strong stem. Bush grows sturdy but rather compact. Color beautiful silvery pink with a rose pink roverse An attractive and satisfactory dahlia.

Tubers, $\$ 2.50$; Plants, $\$ 1.25$ 
JUDGE LEON MCCORD, D. (Boston)-A large flower grown on an absolutely stiff, upright stem. Which does not bend a particle at any season or in any weather. Color is the deepest shade of gold, with a reverse of old rose. Flower reg rlarly formed and lasts a long itime. Medium height bush.

Tubers, \$15.00; Plants $\$ 7.50$

*JERSEY'S BEAUTY, D. (Waite)-This is certainly a beauty and should be grown in every garden on account of its wonderful color and extra fine stems; it is in a class by itself, a most wonderful pink. A prize winner wherever shown.

Tubers, $\$ .75$

*JERSEY'S BEACON, D. (Waite)-Chinese scarlet with a paler reverse, giring a two-toned effect; a very large flower, vigorous grower, good stem.

Tubers, $\$ .7 \overline{5}$

*JERSEY'S SOVEREIGN, D. (Waite)-A new shade hard to describe, a beautiful orange; flowers are good size on fine stems; free bloomer.

Tubers, $\$ .75$

*JERSEY'S SUPREME, D. (Waite)-A rery pleasing shade of clear laelia pink, flowers medium size; free bloomer with gocd stems.

Tubers, $\$ .75$

*JERSEY'S IDEAL, D. (Waite)-Dark larender pink, flowers large and oi splendid formation and borne face up on top of the stem, and the long: petals falling down make a very deəp ficwer.

Tubers, $\$ 1.25$; Plants, $\$ .75$

*JERSEY'S EMPRESS, D. (Waite)-Anthracene riolet in color, the flowers have a very pleasing formation with narrow and wavy petals. Blooms are enormous but stems are somewhat fleshy. A sunproof bloom recommended for exhibition.

Tubers, \$1.50; Plants, $\$ .75$

*JANE COWL, D. (Downs Dahlia Farms) - Deep massive bloom of bronzy buff and old gold, blending darker towards the perifect center. Broad petals, with just enough twist to add the refinement so often lacking in the largest dahlias. A stem of unusual strengtin holds this giant decorative orer a bush of ideal growth, while the foliage is the thick leathery kind that insects seldom bother. Winner wherever shown.

Tubers, $\$ 7.50 ;$ Plants, $\$ 3.75$

*KING SOLOMON, H. C. (Andrews) - A beautiful orange buff with an irrides. cent sheen on the twisted petals, forming an exceptionally boautiful dahlia. Good stem and profuse bloomer and it can truly be said that "Solomon in all his glory was not arrayed as one of these."

Tubers, $\$ 1.00$

*KATHLEEN NORRIS, D. (Fisher \& Masson)-A bloom of gigantic proportions, probably the greatest pink decorative dahlia in commerce. Color a true rose pink, later deepening to mallow pink, but paler in the young central petals. Broad overlapping petals with twisted ends, never showing an open center. Great bloomer and excellent keeper: bloom stands right up on the stem. Tubers, $\$ 10.00$; Plants, $\$ 5.00$

*KING MIDAS, D. (Peacock) - A mammoth, golden yellow flower of great depth on good stems and rery large. Center full and high and never opens. Sturdy bush.

Tubers, $\$ 10.00$ Plants, $\$ 5.00$

LILLIAN MILLER, D., (BroomalI) - A large decorative of fine exhibition form. In color an unusual shade of pomegranite-purple that adds to its beauty. This dahlia will make a worthwhile addition to any collection where something different is desired.

Tubers, $\$ 10.00 ;$ Plants, $\$ 5.00$ 
LA RODA, D. (Broomall)—Silvery rose pink; large well formed flowers held erect on strong stems. Bush growth, medium height.

Tubers, $\$ 7.50 ;$ Plants, $\$ 3.75$

LAVENDULA, D. (Broomall)-The color is a pleasing shade of lavender throughout. It is a strong grower with fine stems and habit, while the bloom itself is very large. Tall grower. One of the best cut flowers to date.

Tubers, \$1.50; Plants, \$.75

MRS. ALFRED B. SEAL, D. (Seal)-Undoubtedly the largest and finest pure, rich, glowing old rose dahlia ever produced. Flowers are large and of great depth and substance, and are leld proudly erect above a fine tall handsome bush. Winner wherever shown.

Tubers, $\$ 15.00 ;$ Plants, $\$ 7.50$

MILDRED BROOKS HOOVER, H. D. (Broomall)-The originator considers this one of the best dahlias in his gardens as the color, spinel-red, is so different. A most distinct and refined flower of large size and splendid form.

Tubers, $\$ 10.00 ;$ Plants, $\$ 5.00$

MAIDEN'S BLUSH, H. D. (Broomall)-An immense flower and a model for shape and habit of growth, and, above all, its remarkable and distinct color, a very light rose pink or blush. Bloom a little soft for cutting.

Tubers, $\$ 15.00 ;$ Plants, $\$ 7.50$

MRS. ELEANOR MARTIN, D. (Pelicano)-One of the finest we grew last year; a giant flower on good stems. Color is mulberry, suffused with gold.

Tubers, $\$ 1.00$

MARIAN BROOMALL, H. C. (BroomalI)-Pink and white, descendant of Gladys Sherwood, but more cactus in shape than that variety and with better stems and habit. Very beautiful and one of the best cut flowers in our garden. Grows 12 inches across.

Tubers, $\$ 1.50 ;$ Plants, $\$ .75$

*MARGARET MASSON, D. (Fisher \& Masson)-A beautiful silvery rose pink of great depth and size. Wonderful exhibition variety on account of its good keeping qualities and fine upright stem.

Tubers, $\$ 1.00$

*MARGARET WOODROW WILSON, D. (Fisher \& Masson)-Color is opalescent pink, with face of petals creamy white, reverse phlox pink. A very large blossom with good stem.

Tubers, $\$ 1.00 ;$ Plants, $\$ .75$

MARMION, D. (Tyler)-Color is pure golden yellow with bronze suffusion on reverse of petals, deeper bronzy tone on high center and outer edges of petals. Florets long, wavy and curly; form perfect; prolific bloomers. The long cane like stems hold the huge blooms 'erect.

Tubers, \$1.50; Plants, $\$ .75$

MIRAFLORA, C. (BroomalI)-White tinted violet-pink, the petals are long, straight and rather narrow. The flowers, 8 to 10 inches without disbudding, are borne profusely on first-class stems. There is nothing like it in dahlias.

Tubers, $\$ .75$

*MY MARYLAND, H. C. (Downs Dahlia Farms)-A bloom of unusually deli cate pink with the faintest suggestion of lavender. The petals are tijped with ivory, anc are pointed and whorled and twisted in a daintily attractive manner all their own. The bloom is large, the stem is good, and the plant is one of those bushes with leatherlike foliage.

Tubers, $\$ 7.50$; Plants, $\$ 3.75$ 


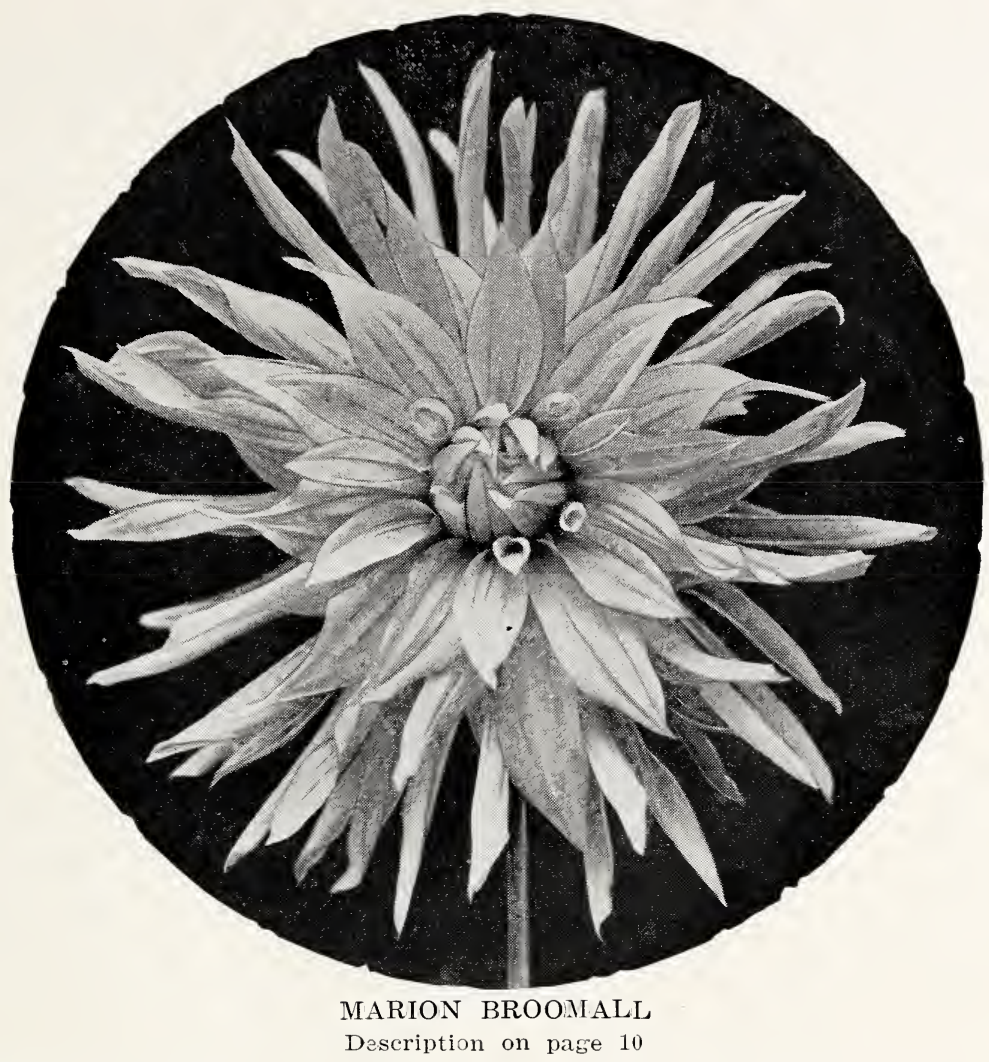

MINNIE EASTMAN, H. C. (Eastman)-Tliis fine introduction has been a persistent winner at the Baltimore and Maryland Dahlia Society Shows. It is a beautiful bloom of a bright flame color with undershadings of deep yellow. Stems long and erset. Sturdy bush.

Tubers, $\$ 7.50$; Plants, $\$ 3.75$

NETAWAKA, H. D. (Broomall)-Orange yellow base shading to jasper red. reverse of petals bright carmine. The petals are twisted so that the reverse color is very much in evidence. The large flowers are born: on good stems, very distinct and pleasing both in form and unusual coloring.

Tubers, $\$ 5.00$; Plants, $\$ 2.50$

NANCY SUE LANG, H. D. (Broomall)--Immense star like flowers, red tipped gold; good stem. Although plant is a dwarf grower it is very robust.

Tubers, \$2.50; Plants, \$1.25

ORANGE GOLD, H. C. (Broomall)-Rich orange-yellow, medium large, good free-blooming habit, producing full-centered flowers in abundance until frost.

Tubers, $\$ .75$

PRIMULA REX, D. (Broomall)-Very light cream or primrose color; one of the best of its kind in existence; the flowers are immense with every good quality; medium grower.

Tubers, $\$ 2.00$; Plants, $\$ 1.00$ 


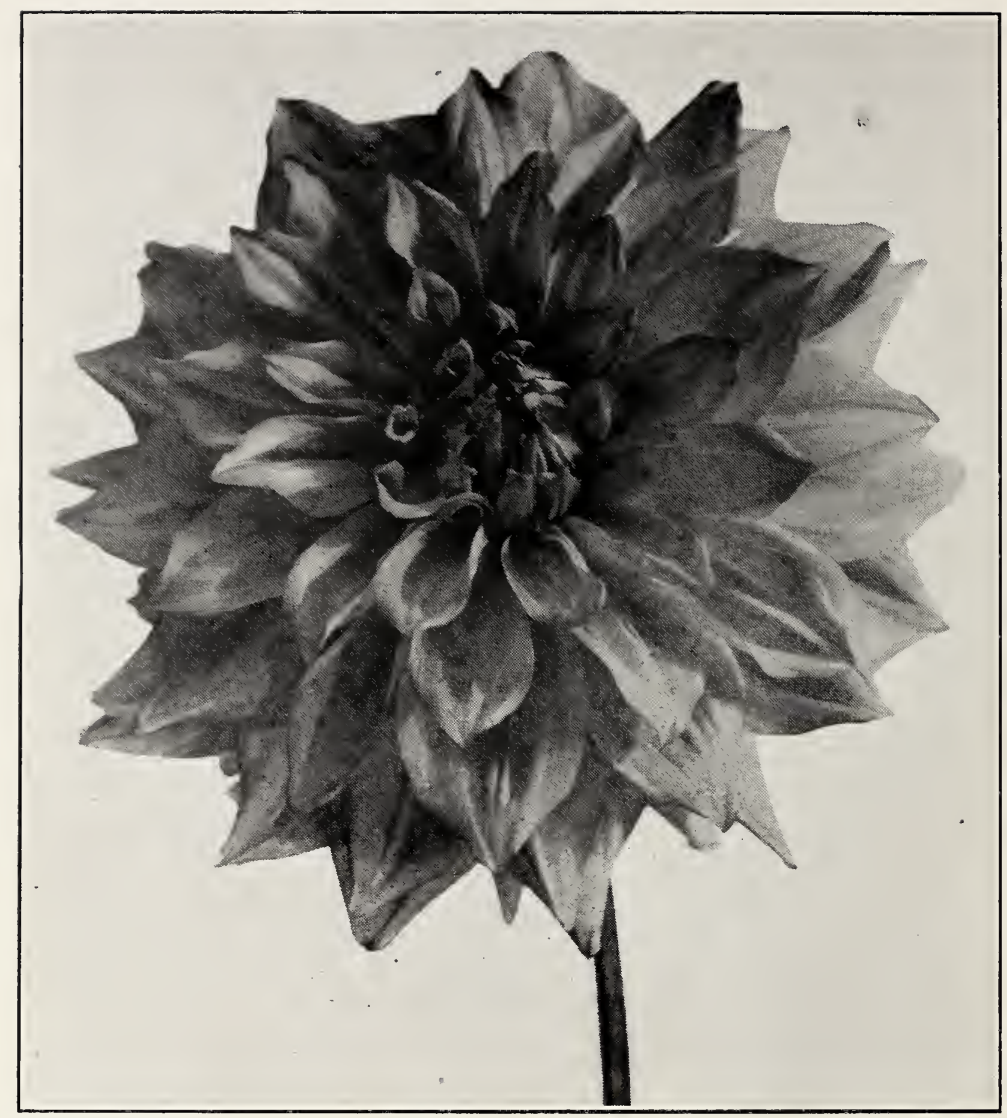

ELITE GLORY

Description on page 5

*POP STEWART, D. (Fisher \& Masson)-A remarkable flower cf great size. A rosy pink, but as the flower matures it tones out into a most exquisite shade of the purest lilac pink. Wonderful grower, profuse bloomer with splendid stem and a great prize winner. Tubers, $\$ 1.00$; Plants, $\$ .75$

PAPILLON, H. C. (Boston)-Large cld rose with yellow shadings, good form, free bloomer, good stem.

Tubers, $\$ 1.00$; Plants, $\$ .75$

PRIDE OF STRATFORD, D., (M. \& S.)-Predominating color, cadmium orange shading to light orange at the base of petals, reverse rose doree. Very large flowers on strong stems. Tubers, $\$ 1.00 ;$ Plants, $\$ .75$

QUEEN OF THE GARDEN BEAUTIFUL, D. (Burns)-It is a large primros: yello,w with a strong stem, perfect type. A flower that fulfilis the dream of Dahlia lovers. Ore of the largest of ali Dahlias measuring from nine to twelve inches acrosis, grown without forcing. The stems are usually strong and is a wcnderful keeper. Tubers, $\$ 1.50$; Plants, $\$ .75$ 


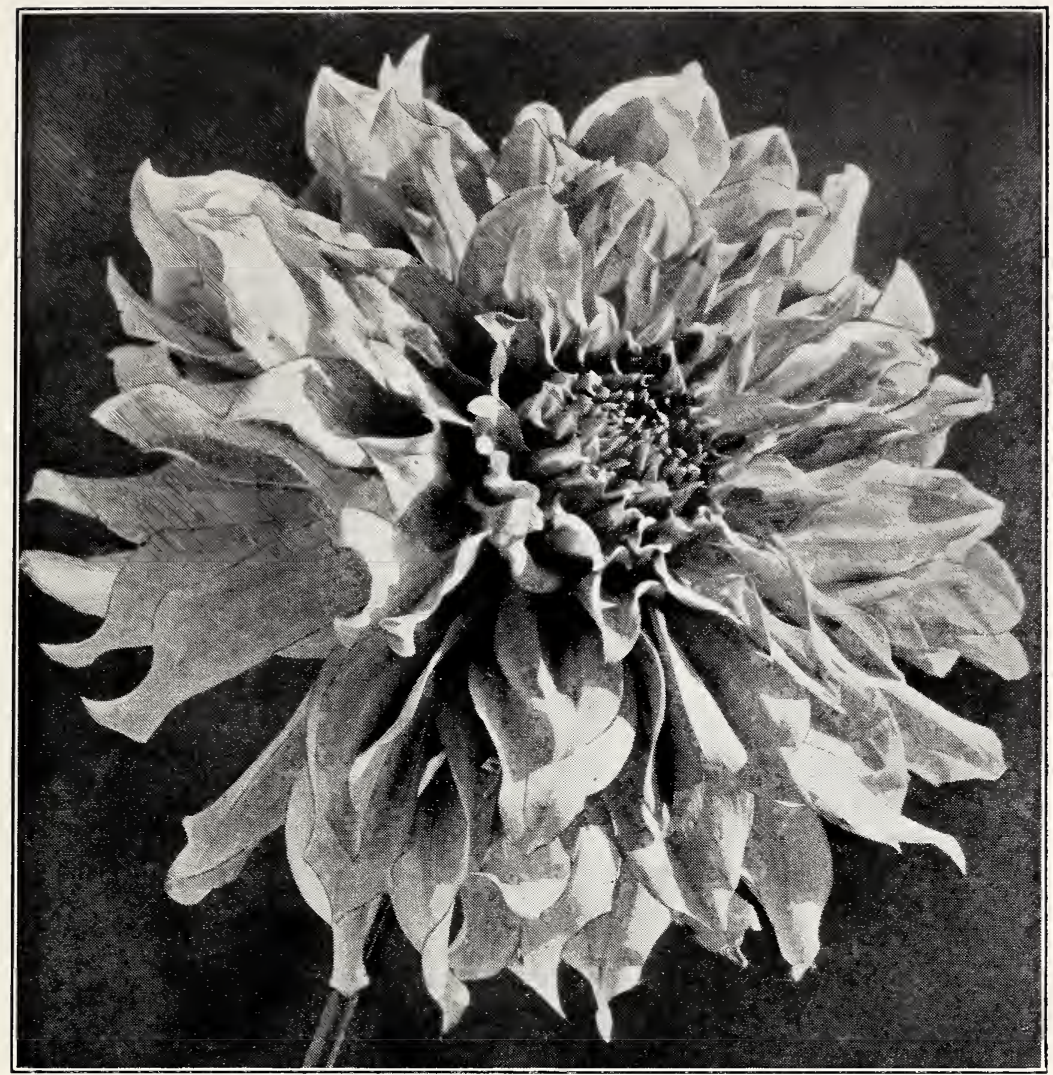

JANE COWL

Description on page 9

*ROMAN EAGLE, D. (Fisher \& Masson)-An immense autumn colored dahlia of a flaming, brilliant burnished copper; much admired in the Eastern shows. Good stem; medium height plant. Tubers, $\$ 1.00 ;$ Plants, $\$ .75$

ROSE FALLON, D. (Harding)-Color is deep old goid, a most perfectly formed giant with good stems and able to stand for days after being cut. Air outstanding variety; winner wherever shown.

Tubers, $\$ 1.50$; Plants, $\$ .75$

REGAL, D. (Boston) - The plants grow medium height and are one of the first to bloom. Blooms on rigid stems well above the foliage. Color, a delightful combination of autumn shades, bronze, heavily suffused with dull old rose, and shading to gold at the base of the petals, giving an effect of burnished copper. One of the largest and best dahlias from the Pacific coast.

Tubers, $\$ 7.50$; Plants, $\$ 3.75$ 
RICHELIEU, D. (Redfern) - A deep velvety red of the oid Jack Rose. (Phlox purple). Sturdy bushes ;with an abundance of flowers carried at right angles to the strong, straight stems. An exhibition and cut flower variety that keeps a long time after being cut. Tubers, $\$ 4.00$; Plants, $\$ 2.00$

ROSE-ELLEN VARBLE, H. C. (Broomall)-In color it is an entireiy new shade of exquisite old rose and coral pink. The foliage grows up to the flower but by disbudding the habit is such that it can be grown with long straight stems.

Tubers, $\$ 10.00$; Plants, $\$ 5.00$

SANTA BARBARA, D. (Pelicano)-The outstanding new dahlia of the 1929 Paıace Hotel Show. The color is an intense clear pink, with a suggestion of a suffusion of salmon pink. Blooms high above the foliag on stems stiff as canes, and look one squarely in the face. Sturdy, medium tall bushes. Net prices.

Tubers, $\$ 10.00 ;$ Plants, $\$ 5.00$

SISKIYOU, H. C. (Broomall)-A wonderful introduction that has created a sensation wherever shown. Grows 9 to 11 inches without forcing. Color, pink tinged mauve. Plants are diwarf but sturdy and vigorous and the flowers are held perfectly erect on strong stems.

Tubers, $\$ 1.00$; Plants, $\$ .75$

SILVERADO, C. (Seal)-The immense bloms are of white, gradually shad. ing toward the center to a delicate silvery lavender. Bush growth tall, stems extra long and strong.

Tubers, $\$ 2.50$; Plants, $\$ 1.25$

*TRENTONIAN, D. (Fisher \& Masson)-A large flower of an Indian skin color, a blending of old gold, amber and coppery bronze. Highly recommended for either garden or exhibition on account of its size, stem and color.

Tubers, $\$ .75$

*THE WORLD, D., (Dahliadel)-The coloring is an unusually rich, deep, rosy magenta overlaid garnet with silver shadings on edge of petals. A rich and beautiful combination of colors. Perfect full centers. Stems are strong and erect.

Tubers, $\$ 7.50$; Plants, $\$ 3.75$

*THOMAS A. EDISON, D., (Dahliadel)-This gorgeous new royal purple exhibition dahlia has met with complete approvai. The staghorn petal formation, the dark green insect-resistent foliage, the can stiff stems, and its thrifty growing habit leave nothing to be idesired.

Plants only, $\$ 10.00$

UNCLE REMUS, D. (Broomall) - Rhodamine purple; large flowers on extra strong stems; an extra strong grower.

Tubers, $\$ .75$

*WALDHEIM SUNSHINE, D. (Peacock)-The most remarkable new dahlia of last year. The true deep yellow that will show up yellow under artificial light. The reflex is darker, and thers is a rich golden suf. fusion around the beautiful, full high center. The form is beautiful, with long wavy, twisted and whorled petals, which relieve the immonse size from stiffness. The stem is long and stiff, holding the flower from facing to upright. The plant is a very strong, sturdy grower.

Tubers, $\$ 5.00$; Plants, $\$ 2.50$ 


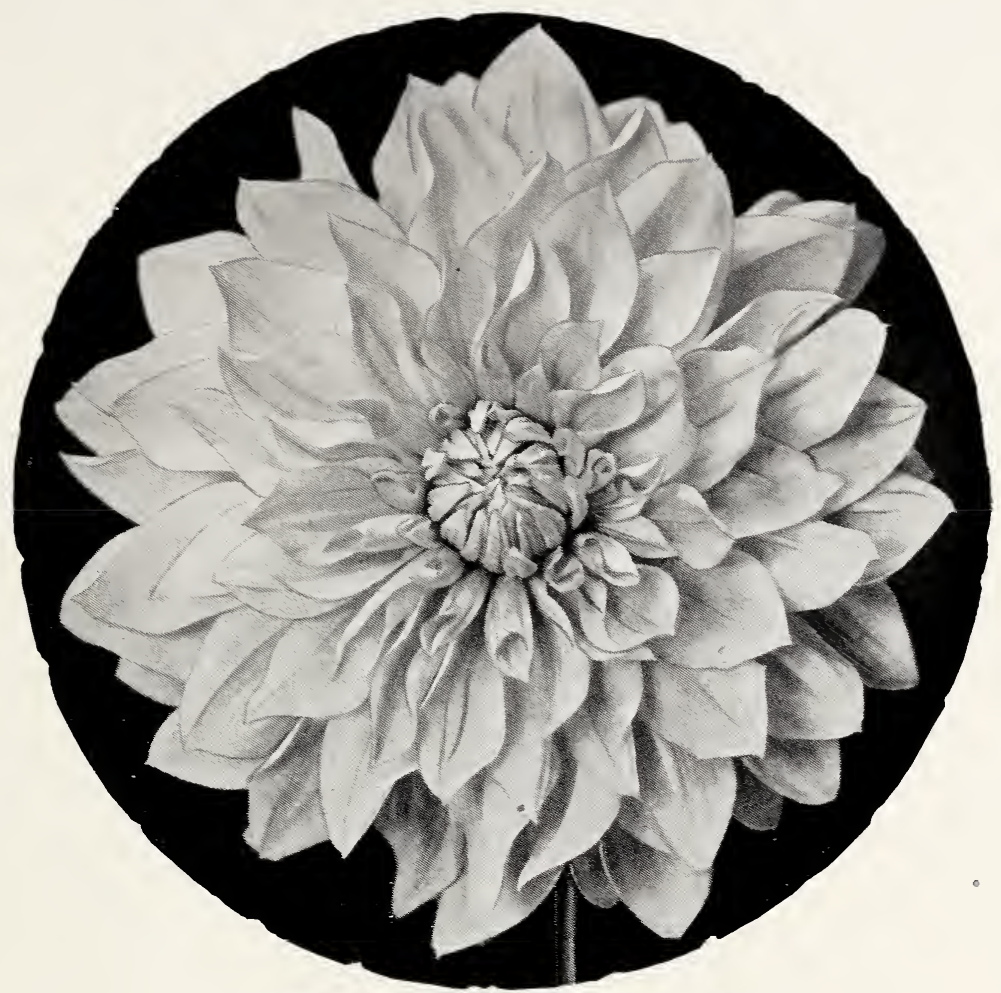

QUEEN OF THE GARDEN BEAUTIFUL Description on page 12

*WATCHUNG SUNRISE, D. (Smith)-In color it is a golden amber with the reserve of petals showing rose pink and each petal edged rose pink, making it very distinctive. Flowers are massive on strong, erect stems.

Tubers, $\$ 5.00$; Plants, $\$ 2.50$

\section{CHOICE MIXTURE IN DAHLIAS}

We are in position this year to offer the gretest value in mixed tubers that we believe has ever been offered the buying public. Made up of varieties listed in this catalogue and all labelled. Price, per collection of six, $\$ 3.00$; per dozen, $\$ 5.50$. Sent postpaid and guaranteed to reach you in good growing condition.

\section{UNLABELLED DAHLIAS}

We will send you twelve dahlias made up of good varieties for $\$ 3.00$. These dahlias are not all labelled and no two alike will be sent out.

$$
\text { DAHLIA SEED }
$$

Owing to the fact that we harvested more seed than we need for our own planting, we will dispose of a limited amount. These seed should be as good as can be purchased anywhere as there were no poms or singles within a mile of our gardens.

Packet of 100 seeds, mixed varieties, $\$ 3.00$.

Packet of 100 seeds, selected from the most outstanding varieties, $\$ 5.00$. 


\section{NEW DAHLIA CLASSIFICATIONS}

Class 1. Single Dahlias. Open centered flowers with only one row of ray florets rgardless of form or number of florets. For example, Newport Wonder, Fugi San, Eckford Century, Coltness Gem.

Class 2 Anemone Dahlias. Open centered flowers with only one row of ray florets regardless of form or number of the florets with the tubular disc floreis elongated, forming a pin cushion effect. For example, Adda Finch.

Class 3. Collarett Dahlias. Open centered flowers with only one row of ray florets with the addition of one or more rows of petaloids, usually of a different color, forming a collar around the disc. For example, Diadem, San Mateo Star, Ami Nonin, Geant de Lyon.

Class 4. Duplex Dahlias. Open centered flowers with only TWO rows of ray florets regardless of form or numbe: oi florets. For example Golden Sunshine, Mrs. J. Coissard.

Class 5. Peony Dahlias. Open centered flowers with not more than THREE rows of ray florets regardless of form or number of florets, with the addition of smaller curled or twisted floral rays around the disc. For example, Geisha, Gorgecus, City of Portland.

Class 6. Incurved Cactus Dahlias. Fully double flowers with the margains of the majority of the floral rays revolute for one-hali or more of their length. The floral rays tending to curve toward the center of the flower. For example, F. W. Fellows, Bearclaws, Farncot.

Cass 7. Recurved and Straight Cactus Dahlias. Fully double flowers with the margains of the majority of the floral rays revolute for one half of their length or more, the floral rays being recurved or straight. For example, Ambassador.

Class 8. Semi-Cactus Dahlias. Fully double flowers with the margain of the majority of the floral rays revolute for less than one-half of their length. For example, Edna Ferber, Francis Lobdell, Sunkiss, Alice Whittier.

Class 9-Formal Decorative Dahlias. Fully double flowers, floral rays generally broad, either pointed or rounded at tips with outer floral rays tending to recurve and central floral rays tending to be cupped; all floral rays in a somewhat regular arrangement. For example, Regal, Sagamore, Jersey's Beauty, Glory of Monmouth, Trentonian, Mrs. I. de Ver Warner, Judge Marean.

Class 10. Informal Decorative Dahlias. Fuily doukle flowers, floral rays generally long, twisted, or pointed and usually irregular in arrangement. For example, Ft. Monmouth, Jane Cowl. Barbara Reäfern, Mrs. Alfıed B. Stal, Insulinde, Kathleen Norris.

Class 11. Miniature Decorative Dahlias. Fully double flowers, floral rays not revolute confroming to the definitions for either the formal or informal decorative types, and less than three inches in diameter. For example. Little Jewel.

Class 12. Ball Dahlias. Fully double flowers, ball shape or slightly flattened, floral rays in spiral arrangement, blunt or rounded at tips and quilled or with markedly involute margins, two irches or more in diameter.

Class 13. Pompon Dahlias. Having same characteristics as Ball dahlias but less than two inches in diameter.

Class 14. Unclassified Dahlias. 

